\title{
System Dynamic Approach to Support Decision in Maintaining Water Availability (Case Study in Aek Silang Sub-Watershed, the Lake of Toba)
}

\author{
Irwan Valentinus Sihotang ${ }^{*}, 1$, Sudarmadji ${ }^{2}$, Ig.L.Setyawan Purnama ${ }^{2}$ and M. Baiquni ${ }^{2}$ \\ ${ }^{1}$ Doctoral Program of Environmental Sciences, UGM, \\ Jl. Teknika Utara, Bulaksumur, Yogyakarta 55281. \\ ${ }^{2}$ Faculty of Geography UGM, Jl. Kaliurang, Bulaksumur, Yogyakarta 55281 \\ ") Corresponding author (e-mail: irwanvalen.sihotang@gmail.com)
}

\begin{abstract}
Water availability is immensely affected by the correlation among land use change, rainfall change, and population growth. One of analysis tools to discover how the correlation goes on in a hydrological process is by dynamic modelling approaching. The dynamic modelling result can be used for a substructure in decisions making as supports to maintain water availability for fulfilling domestic needs, agriculture, and Micro-Hydro Power (MHP). The aims of this study are to evaluate water availability as a long-term impact on land use change, rainfall change, and population growth with dynamic modelling and as a scenario which is required as basic information to make decisions in maintaining water availability. Analysis method which is applied in this study is dynamic modelling to long term evaluate water availability and validate using Mean Average Percentage Error method (MAPE). The analysis showed that the combination of rainfall of $2312.09 \mathrm{~mm} / \mathrm{yr}$, rainfall intensity of $0.340 \mathrm{~mm} / \mathrm{h}$, population growth rate of $7.23 \%$, declined forest area of $1.513 \mathrm{ha} / \mathrm{yr}$, declined shrub/unproductive land of 318.113 $\mathrm{ha} / \mathrm{yr}$, increased agricultural land of $7.627 \mathrm{ha} / \mathrm{yr}$, and increased settlement area of $0.473 \mathrm{ha} / \mathrm{yr}$, yielded the estimation of the fail in sustaining water sources in 2090 or the next 79 years from 2011 since the water deficit has reached approximately 3,249,881.02 $\mathrm{m}^{3}$. The value of validation modelling with MAPE method is 8.90, it is a dynamic modelling which is managed nearly the same with actual condition.
\end{abstract}

Keywords: land use, population growth, water consumption, water availability, dynamics modelling.

\begin{abstract}
Abstrak. Hubungan antara perubahan penggunaan lahan, perubahan curah hujan dan pertumbuhan penduduk sangat mempengaruhi ketersediaan air. Salah satu alat analisis untuk mengetahui bagaimana hubungan tersebut terjadi dalam suatu proses hidrologi adalah dengan pendekatan pemodelan dinamis. Sehingga, hasil pemodelan dinamis tersebut dapat digunakan sebagai dasar pengambilan kebijakan sebagai upaya mempertahankan ketersediaan air untuk memenuhi kebutuhan domestik, persawahan dan micro-hydro power (MHP). Tujuan pemodelan adalah untuk mengevaluasi ketersediaan air sebagai dampak perubahan penggunaan lahan, perubahan curah hujan dan pertumbuhan penduduk dalam jangka panjang dengan pemodelan dinamis dan skenario yang dibutuhkan sebagai dasar untuk mempertahankan ketersediaan air. Hasil penelitian menunjukkan bahwa dengan curah hujan 2.312,09 mm/tahun dan intensitas curah hujan 0,340 mm/jam, laju pertumbuhan penduduk 7,23\%, penurunan luas lahan hutan 1,513 ha per tahun, penurunan semak belukar/lahan tidak produktif 318,113 ha per tahun, peningkatan lahan pertanian 7,627 ha per tahun dan peningkatan kawasan pemukiman 0,473 ha per tahun, maka keberlanjutan air tidak tercapai pada tahun 2090 atau 79 tahun yang akan datang dari tahun 2011 karena keberlanjutan air sudah defisit sebanyak 3.249.881,02 $\mathrm{m}^{3}$. Validasi model sebesar 8,90 artinya model yang disusun hampir menyerupai kondisi aktual.
\end{abstract}

Kata kunci : penggunaan lahan, pertumbuhan penduduk, pemanfaatan air, kelestarian air, model dinamis 


\section{Introduction}

Land use design which is less attention to land condition will guide damage to water system, it interferes water resource availability and not be able to fulfil water need of humans, animals, plants, agricultures, and industry electricity (Muta'ali, 2011). According to The Indonesia National Board for Disaster Management (2015) that the disruption of water availability in several regions of Indonesia, including Magelang, Gresik, and East Nusa Tenggara Province.

The changes in landscape, landform, and land use will affect the hydrological system, which is related to the amount of surface flow, water flow, water quantity and quality, reservoir, runoff, ground water flow and in which at specific level of moisture, the water will transform into subsurface flow and base flow (Liu, 2005; Hartono, et al., 2006; Asdak, 2010; Indra, 2013).

Land use changes, in fact, are closely associated with the precipitation changes. However, land use for forest vegetation was evidenced to possess high evapotranspiration and humidity level in compared with other covers, which led to higher rainfall level in the region. The higher the rate of forest land conversion, the higher the rate of rainfall disruption (Zeppel, et al., 2014; Asner, et al., 2010; Igbawua, et al., 2016; Asdak, 2010).

The water availability becomes a serious problem when the demand constantly increases, while the water supply is declining. The hydrological phenomenon is very complex and it is very difficult to understand it entirely (Indarto, 2010). Thus, models to simplify and facilitate the phenomenon is required, one of the models is the dynamics model. Some positive points of dynamic modelling are increasing the understanding about phenomenon easier, forecast, and decision making easier (Purnama, et al., 2006; Chung, et al., 2008, Hartrisari 2007, Purnomo, 2012).

Jiang, et al., 2012; Mirchi, et al., 2012; Kotir, et al., 2016 explained that the impact of changes in factors, affect to water availability, such as land use change, rainfall change, and type of water use can be known by applying dynamic modelling system. Besides, the function of dynamic modelling is to inform the long term condition of water availability, whether it can fulfil water need in the future or not.

The result of dynamic modelling from scenario result which was conducted towards water availability factors rainfall change, land use change, and population growth can be used as substructure consideration in decision making to support the maintaining of water availability (Xi and Poh, 2013; Kotir, et al., 2016).

Toba lake is the largest lake in Indonesia $( \pm$ 116.002,06 ha), has one of sub-watershed which remains running its function as permanently water supplier (a whole year) to Toba Lake named Aek Silang Sub-Watershed (19.814,72 ha). Not only running for fulfilling domestic needs but also for agriculture and Micro-Hydro Power (MHP). In the other hand, the rate of land use change in Aek Silang Sub-Watershed is high, it affects to water availability in the area. According to Ministry of Forestry in the results of the reviews of critical land preparation, 2014 stated that Toba Lake watershed is in the priority list to be rehabilitated. By applying dynamic modelling, this study will generate some activities to rehabilitate Toba Lake watershed efficiently and effectively.

The aims of this study are to evaluate water availability as the long term impact of land use change, rainfall change, and population with dynamic modelling and as a scenario which is required as basic information to make decisions in maintaining water availability.

\section{Research Methods}

\section{a. Time and Study Area}

This study was carried out in July 2014 to October 2014. Precisely, the study area was Aek Silang sub-watershed located in Lake Toba Catchment Area (LTCA), North Sumatera Province $\left(02^{\circ} 15^{\prime} 00^{\prime \prime} \mathrm{N}-02^{\circ} 30>00 » \mathrm{~N}\right.$ and $98^{\circ}$ $\left.36^{\prime} 00^{\prime \prime} \mathrm{E}-98^{\circ} 56>00 » \mathrm{E}\right)$, as presented in Fig. 2. 


\section{b. Research Design}

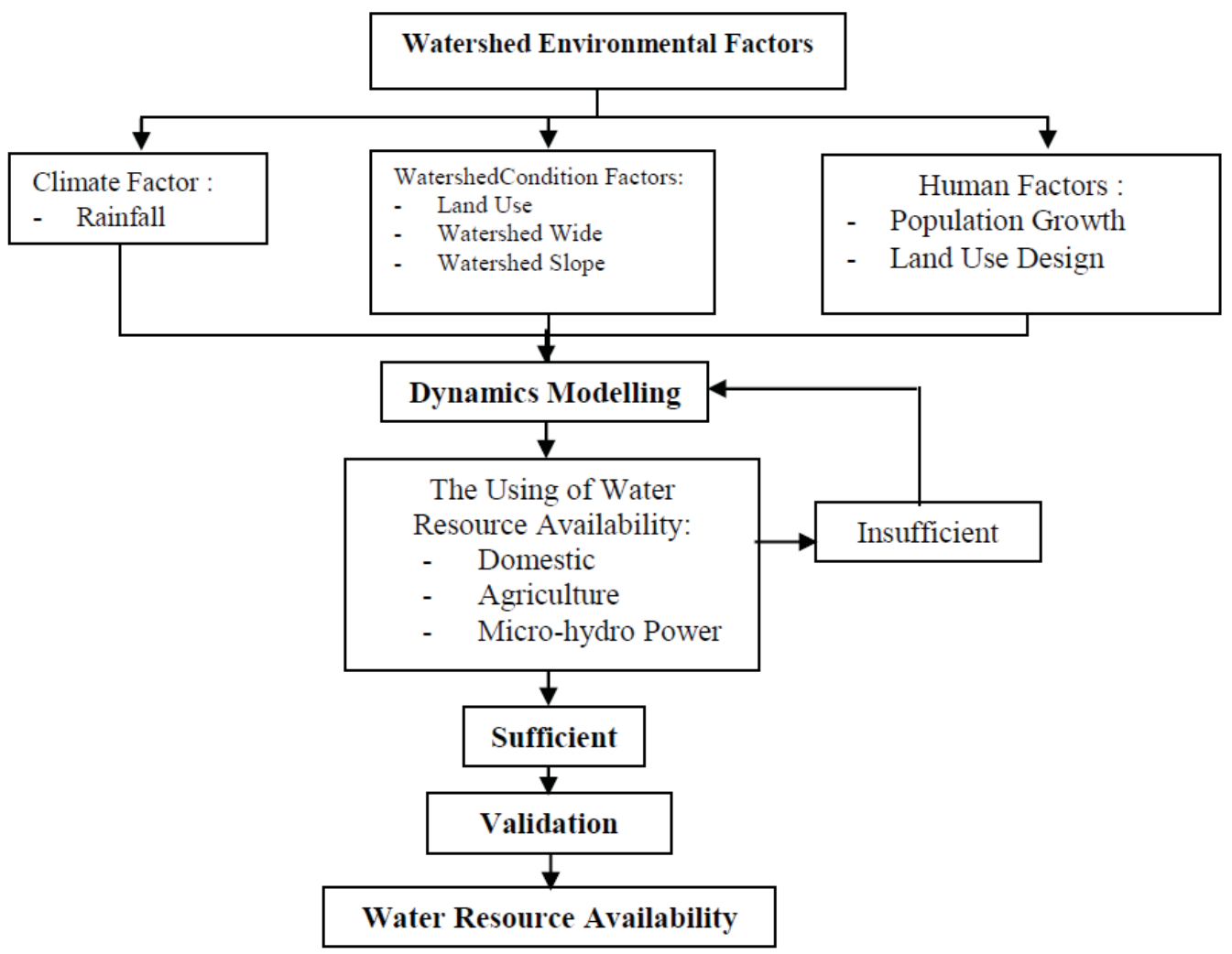

Figure 1. Research Design

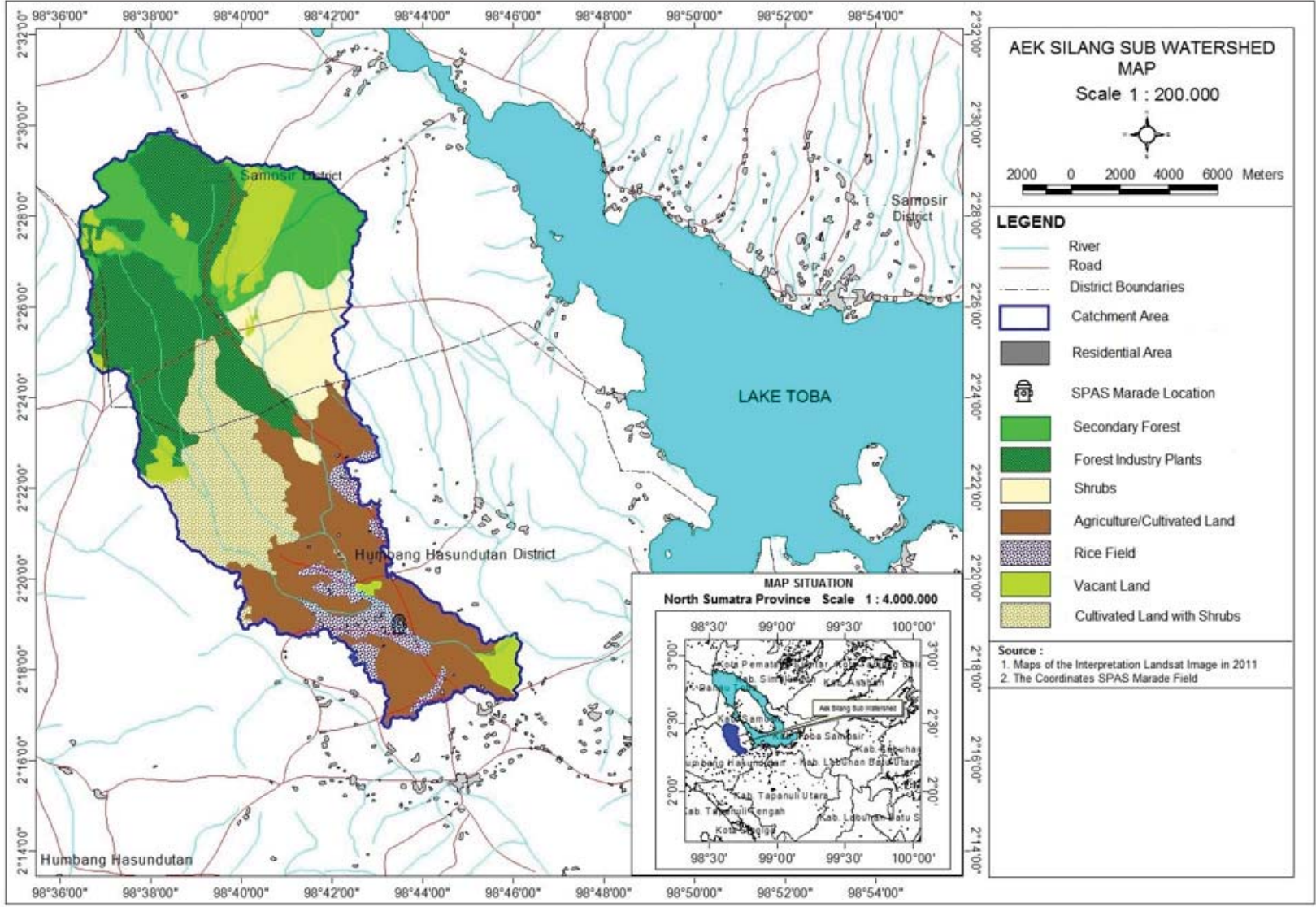

Figure 2. Map of Aek Silang Sub-watershed. 


\section{c. Type of Datum and Assumptions in Dynamic Modelling}

Dynamics modelling is commenced by identifying the problem, making assumptions, constructing the model, determining a suitable analysis, interpreting analysis results, and performing the process of validation and implementation (Hartrisari, 2007; Sitompul, 2009; Wiyono, 2012). Development of a system dynamic modelling (SDM) that captures that the interactions and feedbacks between the population sub-sector, water resource subsector and agricultural production sub-sector (Kotir, et al., 2016). Dynamic modelling was applied by using Software Power Sim 2.5 c. The data since 2011 (based on the collected data) was the input of the modelling that was projected to the next 89 years (2010) to foresee the water availability.

Equations and assumption of each factor which is used in dynamic modelling to calculate water resource availability are mentioned below:

\section{1) Rainfall (Climate Change)}

Estimation of the mean rainfall for undulating or hilly areas is conducted by using
Isohyet method as it is highly accurate with relatively small error level, which is $0.1 \%$ 4.7\% (Purnama 2008; Narulita, 2007). Analysis of rainfall in Aek Silang sub-watershed was carried out in 2003 - 2012 as obtained from 5 (five) rainfall stations including Parapat station, Lae Hole station, Sidikalang station, Gabehutaraja station, and Onan Runggu station. The mean rainfall was used as input to the dynamics modelling that depicted the potential of water sources in Aek Silang subwatershed.

\section{2) Land Use Changes}

Land-use activities that change the landscape of a watershed frequently affect the water yield, time and dispersion of water flow, infiltration, and water holding capacity of the ground (Asdak 2010; Indra, 2013). The value or trend of the rate of each land use change should be minimised with several basic assumptions to maintain the conversed area remains even to the area of Aek Silang sub-watershed.

Basic assumptions related to the changes of land use as the input in dynamics modelling included data of land use/cover changes in 2009 -2011, can be found in Tabel 1.

Tabel 1. Assumption of Land Use Change

\begin{tabular}{lccl}
\hline \multicolumn{1}{c}{ Group of Land Use } & $\mathbf{2 0 0 9}(\mathbf{h a})$ & $\mathbf{2 0 1 1}(\mathbf{h a})$ & \multicolumn{1}{c}{ Assumption of Land Use Change } \\
\hline Forest : & $7.675,61$ & $8.725,59$ & Decreased, 1,51 ha/year \\
- Secondary Forest & $2.542,65$ & $2.538,11$ & Constant (related permission of the \\
- Industrial Forest & $5.132,96$ & $6.187,48$ & government) \\
Dryland Agriculture & $7.674,67$ & $7.679,55$ & Increased, 7,63 ha/year \\
Paddy Field & 984,29 & $1.053,35$ & Constant, community keep working on \\
& & & dryland agriculture. \\
Scrub and open land & $3.419,53$ & $2.276,19$ & Decreased, 381,11 ha/year \\
Settlement & 60,62 & 62,04 & Increased, 0,47 ha/year \\
\hline
\end{tabular}

Source : Result of Interpretation of Citra Landsat 2009 and 2011

In case there was difference between total area of conversed land andtotal area of Aek Silang sub-watershed, the difference was used to increase or decrease total area of dry-land agriculture.

\section{3) Water Demand Fulfillment}

The water utilisation in the area of Aek Silang sub-watershed consisted into 3 (three) main types, namely domestic needs, agriculture, and Micro-Hydro Power (MHP) plant. The standard value of water demand of each sector enclosed in the dynamics modelling is represented in Appendix 3.

\section{4) Calculation Method of Potential Water Utility (V)}

Volume of water utility which can be used in a year is calculated using the equation below:

$\mathrm{V}=\mathrm{Q} * \mathrm{t}$

$\mathrm{Nb}$ :

$\mathrm{V}=$ Volume of using water $\left(\mathrm{m}^{3}\right)$

$\mathrm{Q}=$ water flow $\left(\mathrm{m}^{3} /\right.$ second $)$

$\mathrm{t}=$ time of measurement 1 year

The value of water flow is calculated by using Rational Method calculations developed 
by U.S. Soil Conservation Service in 1973 (Asdak, 2010), with the primary equation as follows:

$Q=0.0028 C I A$

Where:

$\mathrm{Q}=$ Peak runoff rate/discharge $\left(\mathrm{m}^{3} / \mathrm{s}\right)$

$\mathrm{C}=$ Runoff coefficient

I $=$ Rainfall intensity $(\mathrm{mm} / \mathrm{hr})$

$\mathrm{A}=$ Area (ha)

Standard runoff coefficients (C value) of each land use that were included in the rational equation are demonstrated in Table 2.

Table 2. Value of Runoff Coefficient (C) in Rational Calculation Method

\begin{tabular}{clc}
\hline No. & \multicolumn{1}{c}{ Land Use } & C \\
\hline 1. & Undulating land and forest & 0.50 \\
2. & Cultivated land & 0.45 \\
3. & Rice fields/Paddy Field & 0.70 \\
4. & Non-productive land & 0.60 \\
5. & Settlement & 0.40 \\
\hline
\end{tabular}

Source: Takeda (1993) and US Forest Service (1980) in Asdak (2010).

Daily mean rainfall intensity (I) was calculated by using an equation developed by Takeda (1993), as follows:

$I=\frac{R_{24}}{24}\left(\frac{30}{t_{c}+6}\right)$

Where:

I = Rainfall intensity $(\mathrm{mm} / \mathrm{hr})$

$\mathrm{R}_{24}=$ Daily mean rainfall $(\mathrm{mm} / \mathrm{hr})$

$t_{c}=$ Time of concentration or period from the upstream to the observed outlet (hr)

The value of rainfall intensity used in the dynamics modelling was the value that generated the peak runoff rate to supply the demand for agricultural irrigation and power plant. According to Hirijanto, et al. (2013), the peak runoff rate for irrigation and power plant is in the range of $80 \%-95 \%$.

\section{d. Validation Modelling}

Validation in this modelling is conducted by quantitative behaviour pattern comparison (MAPE- Mean Absolute Percentage Error).
MAPE testing can be used to gain information about accuration between data assumption and actual data (Somantri dan Machfud, 2006).

MAPE $=\frac{1}{n} \sum \frac{\left|X_{m}-X_{d}\right|}{X_{d}} x 100 \%$

$\mathrm{Nb}$ :

$\mathrm{X}_{\mathrm{m}}=$ Result data of simulation

$X_{\mathrm{d}}=$ Actual data

$n=$ Period/number of data

- MAPE < 5\%, : modelling is arranged according to actual condition

- MAPE between 5\% - 10\% : modelling is arranged close actual condition

- MAPE > 10\% : modelling is arranged different to actual condition

\section{Results And Discussion}

System dynamics modelling was employed to project the water availability. The concept is derived from a differential equation that is represented by the stock and the flow, thus, it is capable to illustrate the feedback or causality (Soemantri and Machfud, 2006; Purnomo, 2012).

The water sources utilisation in the Aek Silang sub-watershed, Lake Toba Catchment Area, was investigated to determine the status and to reveal the effect of dynamic factors such as population growth and land use changes.

\section{a. Implementation Modelling}

\section{1) Rainfall}

According to rainfall data in 2003 to 2012 in Aek Silang sub-watershed of 5 rainfall station, there are Parapat station, Lae Hole station, Sidikalan station, Gabehutaraja, and Ona Runggu station is resulted the average of rainfall with Isohiet method is listed in table 3.

The average of rainfall is $2.312,09 \mathrm{~mm} /$ year was used as input of rainfall in dynamic model which descibes water resource potential in Aek Silang watershed. Trend the change of rainfall based on Indonesian Agency for Meteorological, Climatological, and Geophysics Sampali, Sumatera Province is decreasing to be $1.97 \mathrm{~mm}$ /year. 
Table 3. Monthly Rain Condition in Aek Silang Sub-Watershed (2003-2012)

\begin{tabular}{|c|c|c|c|c|c|c|c|c|c|c|c|c|c|c|}
\hline \multirow{2}{*}{ No } & \multirow{2}{*}{ Station } & \multicolumn{12}{|c|}{ Rainfall (mm) } & \multirow{2}{*}{$\begin{array}{l}\text { Total } \\
(\mathrm{mm})\end{array}$} \\
\hline & & Jan & Feb & Mar & Apr & May & Jun & Jul & Aug & Sept & Oct & Nov & Dec & \\
\hline 1. & Parapat & 197.50 & 136.80 & 186.60 & 217.90 & 141.70 & 111.00 & 126.30 & 147.00 & 191.00 & 228.60 & 281.90 & 214.60 & $2,180.90$ \\
\hline 2. & Lae Hole & 201.40 & 164.00 & 247.10 & 305.90 & 191.00 & 124.70 & 102.20 & 121.90 & 293.10 & 293.10 & 275.90 & 243.90 & $2,564.20$ \\
\hline 3. & Sidikalang & 257.85 & 149.57 & 273.22 & 319.45 & 170.67 & 139.93 & 150.24 & 159.80 & 215.98 & 220.04 & 272.79 & 266.24 & $2,595.78$ \\
\hline 4. & Gabehutaraja & 244.20 & 212.60 & 211.90 & 260.30 & 124.40 & 160.40 & 138.10 & 175.92 & 190.34 & 254.78 & 286.33 & 255.59 & $2,514.86$ \\
\hline 5. & $\begin{array}{l}\text { Onan } \\
\text { Runggu }\end{array}$ & 116.60 & 106.80 & 222.70 & 183.20 & 71.80 & 109.34 & 112.14 & 146.95 & 204.81 & 279.57 & 223.01 & 221.38 & $1,998.31$ \\
\hline Aver & age (mm) & 189.40 & 145.87 & 226.07 & 246.01 & 130.94 & 125.28 & 125.48 & 148.20 & 218.74 & 260.22 & 262.01 & 236.68 & $2,312.09$ \\
\hline
\end{tabular}

Source : Anaylisis of Rainfall Data, 2016

\section{2) Volume of Potential Utilized Water Resources (V)}

In accordance to previous rational calculation method, the $\mathrm{C}$ value was determined based on the trend of land use as explicated in Table 3 and the A value was total area of Aek Silang sub-watershed $(19,814.72$ ha). Rainfall intensity from equation analysis (3) generated the peak runoff rate of $80 \%-95 \%$ was $0.340 \mathrm{~mm} / \mathrm{hr}$. Volume of potential utilized water resource analyzed by using dynamics modelling yielded the potential utilized water sources in 2011 - 2100 as demonstrated in Figure 3.

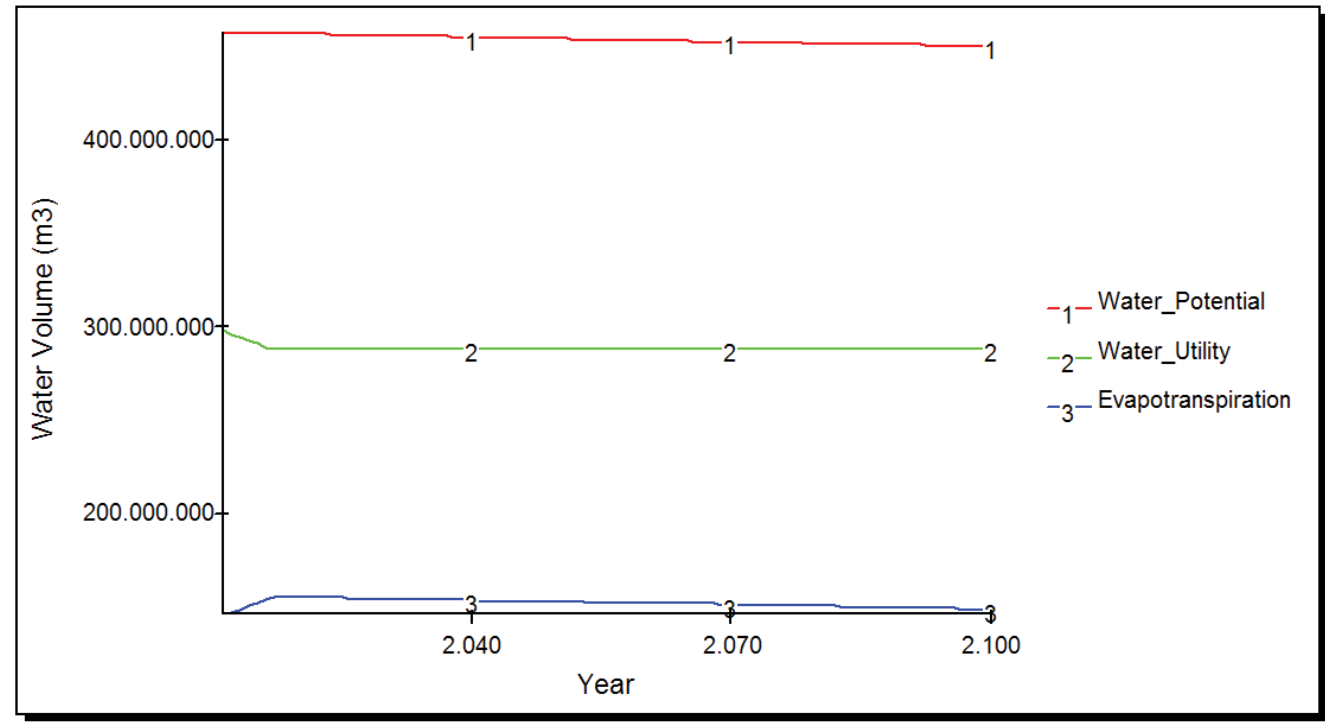

Figure 3. Graphic of The Using of Water Availability

Potential water assessed in this dynamics modelling was derived from rainfall. Rainfall in the area of Aek Silang sub-watershed was the annual mean rainfall, which was 2,312.09 $\mathrm{mm} /$ year with a decreasing trend of rainfall $0.42 \mathrm{~mm} /$ year, so the water potential in Aek Silang sub-watershed was decreasing to be $83.222 \mathrm{~m}^{3} /$ year.

The availability of potentially utilised water (discharge) showed a declining trend from 2011 to 2100. From the projection, the highest water depletion would be in 2011 to 2017 , which is $10,268,346 \mathrm{~m}^{3}$ or approximately $1,711,391 \mathrm{~m}^{3}$ per year. It was allegedly due to the land use change of shrubs/non-productive area that declines as much as 381.113 ha per year and was converted into agricultural land, which caused the leeway of rainfall into a runoff was lower. It was confirmed by Soedarjanto, et al. (2011); Asdak (2010); and Rachmat (2007), who suggested the activities of land use that change a landscape of a catchment area at a large scale and permanently will affect the quantity of water yield, related with the process of evapotranspiration and the water holding capacity of vegetation. The trend of rate of each land use change is shown in the figure 4 . 


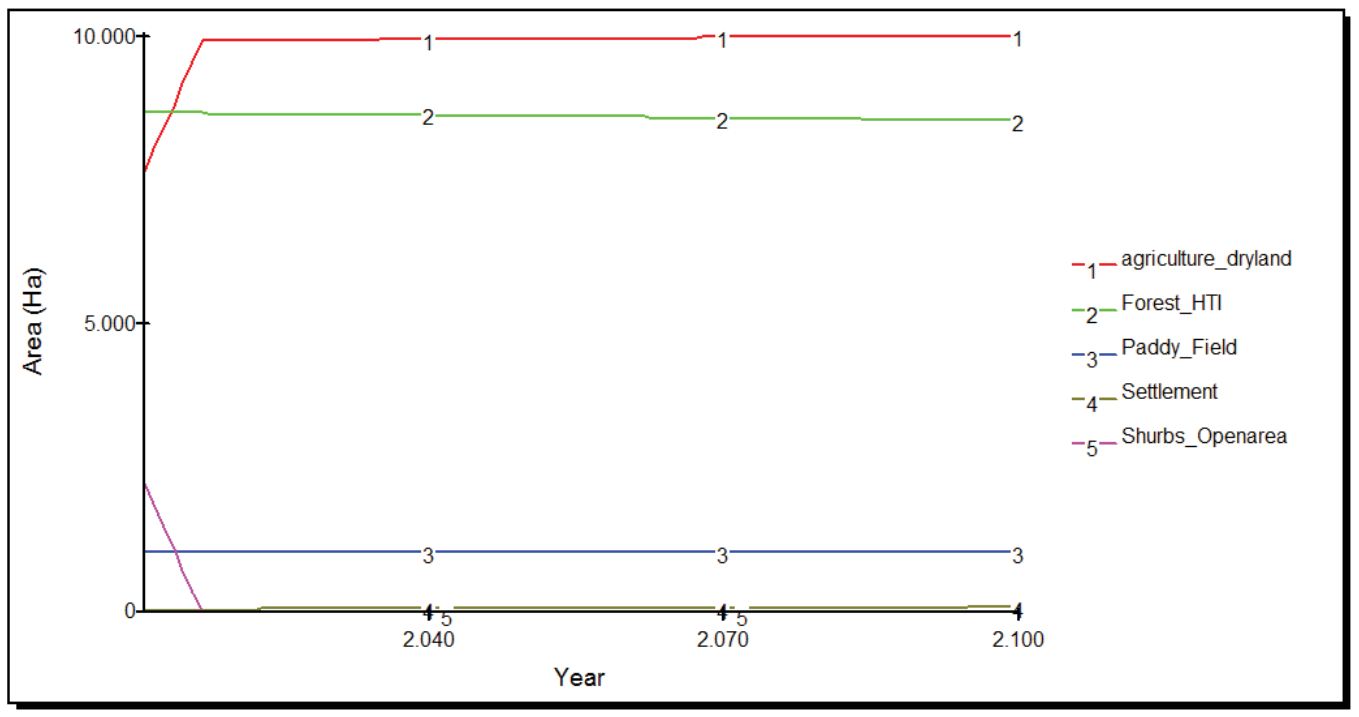

Figure 4. Graphic of The Change of Each Land Use

Evapotranspiration rate as depicted in Table 4 showed an increasing trend throughout the year, which was 146,731,718.02 $\mathrm{m}^{3}$ in 2011 and enhanced into $157,247,505.15 \mathrm{~m}^{3}$ in 2100 . Evapotranspiration in 2011 to 2017 augmented approximately $1,711.391 \mathrm{~m}^{3}$ per year, while in 2017 and the subsequent years it was projected to enhance for $2,981 \mathrm{~m}^{3}$ per year. This condition demonstrated the obvious association between land use type and evapotranspiration rate.

The link between land cover and evapotranspiration is directly proportional, the higher the vegetation growth rate, the higher the evapotranspiration rate. The studies carried out by Zeppel, et al. (2014), Soedarjanto, et al. (2011) and Asner, et al. (2010) concluded that the higher the density of canopy cover, the higher the evapotranspiration rate. It is due to the role of vegetation as a pump in the transformation of ground-water into vapour through the process of transpiration as well as the land use change from vacant land or forest into the agricultural land that affects the albedo, which reduces the soil surface roughness and eventually augments the evapotranspiration rate.

Water holding capacity (WHC) is the ability of soil to hold water which is affected by land use in each soil type. The value of WHC is derived by overlaying land use map and soil type, so WHC in Aek Silang sub-watershed was $126,56 \mathrm{~mm}$ or $25.077 .510 \mathrm{~m}^{3}$. Half of WHC will flow as baseflow, so the water remain in the soil was $12.538 .755 \mathrm{~m}^{3}$. WHC was assumed to remain because the type of the soil did not change.

\section{3) Water Demand Volume}

Total water demand volume for domestic needs, agriculture, and power plant was estimated by using the dynamics modelling (with the values in Table 1 as the inputs), the results is presented in appendix 2. The rate of water demand in Aek Silang sub-watershed demonstrated at appendix 2 the increasing trend from year to year, which is in linear the rate of population growth $(7.23 \%)$ and the rate of death $0,4 \%$, meanwhile the estimated water demand for irrigated field and MHP plant are stable. In 2011, total water demand in Aek Silang sub-watershed was 216,311,714 $\mathrm{m}^{3}$ and it becomes $361,398,834 \mathrm{~m}^{3}$ in 2100 or the next 89 years, on the other words, the water consumption increases approximately $145,087,120 \mathrm{~m}^{3}$ or $67,07 \%$ or $0.75 \%$ per year. Based on Liu and Yaning (2006), it was projected that in during the next 50 years, the water consumption rate in the western part of China will increase as much as $20 \%$, while in the area of Aek Silang sub-watershed, the rate will increase $67,07 \%$ during the next 89 years.

\section{4) Reserve Water Availability Resource}

Reserve water availability is the combination of dynamics model of potential utilised water availability and dynamics model of water demand, which is the difference the discharge and total water demand. The condition of water availability will be attained if the water availability is surplus; hence, there is excess water to be used for other uses. On the 
contrary, if the water supply is lower than deficit. The status of water availability can total water demand, there will be a water be determined as presented in Table 4 .

Table 4. The status of water availability in $2011-2100$

\begin{tabular}{|c|c|c|c|}
\hline Year & $\begin{array}{l}\text { Potential utilized } \\
\text { water }\left(\mathrm{m}^{3}\right)\end{array}$ & $\begin{array}{l}\text { Total water demand } \\
\qquad\left(\mathrm{m}^{3}\right)\end{array}$ & Water availability $\left(\mathrm{m}^{3}\right)$ \\
\hline 2011 & $298,858,733$ & $216,311,714$ & $82,547,019$ \\
\hline 2012 & $297,139,470$ & $216,339,483$ & $80,799,987$ \\
\hline 2013 & $295,420,207$ & $216,369,149$ & $79,051,058$ \\
\hline 2014 & $293,700,944$ & $216,400,842$ & $77,300,102$ \\
\hline 2015 & $291,981,681$ & $216,434,698$ & $75,546,983$ \\
\hline 2016 & $290,262,418$ & $216,470,868$ & $73,791,550$ \\
\hline 2017 & $288,590,387$ & $216,509,507$ & $72,080,880$ \\
\hline 2018 & $288,587,405$ & $216,550,786$ & $72,036,619$ \\
\hline 2019 & $288,584,424$ & $216,594,884$ & $71,989,540$ \\
\hline 2020 & $288,581,443$ & $216,641,994$ & $71,939,449$ \\
\hline 2089 & $288,375,739$ & $286,247,775$ & $2,127,964$ \\
\hline 2090 & $288,372,758$ & $291,052,178$ & $-2,679,420$ \\
\hline 2091 & $288,369,777$ & $296,184,721$ & $-7,814,944$ \\
\hline 2092 & $288,366,796$ & $301,667,817$ & $-13,301,021$ \\
\hline 2093 & $288,363,814$ & $307,525,408$ & -19.161 .594 \\
\hline 2094 & $288,360,833$ & $313,783,073$ & $-25,422,240$ \\
\hline 2095 & $288,357,852$ & $320,468,137$ & $-32,110,285$ \\
\hline 2096 & $288,354,871$ & $327,609,790$ & $-39,254,919$ \\
\hline 2097 & $288,351,890$ & $335,239,218$ & $-46,887,328$ \\
\hline 2098 & $288,348,908$ & $343,389,736$ & $-55,040,828$ \\
\hline 2099 & $288,345,927$ & $352,096,934$ & $-63,751.007$ \\
\hline 2100 & $288,342,946$ & $361,398,834$ & $-73,055,888$ \\
\hline
\end{tabular}

Source: Data analysis, 2016.

Based on the analysis, it was estimated that the water availability in Aek Silang subwatershed will meet the demand until 2089 or the next 78 years, where the water surplus will be 2,127,964 $\mathrm{m}^{3}$. However, in 2090 the water deficit will occur with estimated water demand is $2,679,420 \mathrm{~m}^{3}$. It was predicted that in 2090, as many as 122,348 people will endure water deficit to fulfil domestic needs or 258,43 ha of farmland cannot be cultivated for 114,51 hours (4 days 19 hours) and MHP plant cannot generate electricity. It foresees the water availability sources fails due to at certain period, water supply is a deficit to fulfil domestic needs, agriculture, and MHP plant.

Furthermore, the increased water shortage is mainly caused by the factor of high rate population growth, hence, water demand for domestic needs enhances while the water availability is lessened. The rate of water availability is not proportional with the rate of domestic needs, in which the mean potential water volume is reduced arithmetically, which is approximately $2,981 \mathrm{~m}^{3}$ per year, meanwhile, the population growth exponentially increases, which is $7.23 \%$ per year, even though there is death rate 0,004 or $0,4 \%$ per year.

The water availability is secure if a watershed/catchment area has the capacity to meet the water needs in the present time without disrupting the water supply for the future. Table 5 showed the environmental conditions of Aek Silang sub-watershed indicated the provision of sustainable water in 2089, with the rainfall intensity of $2,279.33 \mathrm{~mm} /$ year, forest cover of $8,607.58$ ha, agriculture/cultivated land of 10,054.86 ha, shrubs/vacant land of 0 ha, settlement of 98.93 ha, rice fields of 1,053.35 ha, and population of 2,408,995 people. 


\section{5) Validation modelling}

The result of dynamic modelling of water availability which can be validated is in the year of modelling started, 2011-2012, and before the year of modelling started, 2003, 2006, 2009. It is concluded that the number of the data is 5 data. Validation modelling in those years can be conducted because supporting data is completely available to run dynamic modelling, for example wide of each land using, the number of human population, and actual water availability data which was collected from River Management on Board North Sumatera Province as comparison standard of simulation data. Dynamic modelling validation of water availability which can be used is performed in table 5 .

Table 5. Dynamic Modelling Validation of Water Availability by MAPE testing

\begin{tabular}{rrrrr}
\hline Tahun & Aktual = Xd & Model = Xm & $\frac{X_{m}-X_{d}}{X_{d}} \mid$ & $\mathbf{x ~ 1 0 0 \%}$ \\
\hline 2003 & $381,639,168.00$ & $324,849,963.00$ & 0.1488 & 14.88 \\
2006 & $328,972,320.00$ & $324,848,935.00$ & 0.0125 & 1.25 \\
2009 & $319,953,888.00$ & $302,034,917.00$ & 0.0560 & 5.60 \\
2011 & $327,258,835.20$ & $298,858,733.00$ & 0.0868 & 8.68 \\
2012 & $345,865,248.00$ & $297,139,470.00$ & 0.1409 & 14.09 \\
\hline & & & $\sum=$ & 44.50 \\
& & & $\mathrm{n}=$ & 5 \\
& & & MAPE $=$ & 8.90 \\
\hline
\end{tabular}

Source : Data analysis result of Powersim 2.5c, 2016

The result of modelling validation is $8.90 \%$, it is stated that condition of dynamic modelling which was conducted close to the actual condition.

\section{b. Model Simulation}

Dynamic modelling construction of potentially utilised water resource which can be profited is performed in Appendix 4, while dynamic model construction of water availability is performed in Appendix 5 .

The condition of water volume which can be utilised from year to year as the impact of land use change (table 1) can be obtained from dynamic modelling construction (Appendix 4). Each land use has different runoff coefficient (C), so that every change of wide of land use generates to the change of runoff coefficient in Aek Silang Sub-Watershed Lake Toba. That case will change the volume of water which can be used $(\mathrm{V})$. The simulation of land use change can be done to gain information related the volume of water which can be utilised in order to fulfil water need.

Dynamic modelling construction (Appendix 5) results in the condition of water availability, whether the water can be utilised to meet water need or not. The simulation to achieve long-term water availability in fulfilling water need can be done on some controllable factors such as the rate of land use change and the rate of population growth.

\section{c. Design of Scenario to Reserve Water Resource}

\section{1) Decreasing Population Growth Rate}

The decline of population growth rate is a factor whichmight becomea solution to preserve the water availability. The expected population growth rate is equal to the national population growth rate, which is $1.4 \%$. The population growth rate in 2100 with a growth rate of $1.4 \%$ is 33,757 people. With an assumption, the water consumption for domestic needs is 80 litres/individual/day, the volume of water demand is $985,710 \mathrm{~m}^{3}$ and the total water consumption (domestic + agriculture + MHP plant) is $216,890,843 \mathrm{~m}^{3}$. It is projected that in 2100 , the volume of water utility is $288,342,946$ $\mathrm{m}^{3}$ and the water availability is $71,452,103 \mathrm{~m}^{3}$. It means that with a population growth rate of $1.4 \%$, water availability can be attained.

The reduction of population growth rate from $7.23 \%$ to $1.4 \%$ requires the role of the government and also the support from the society. The government can promote this solution through education, counseling, provision of facilities and infrastructure, in order to disseminate the knowledge and skills to the society, such as perception, behavior, world view, and cultural values that can establish local wisdom (Yulianto, 2007) to support population control, and ultimately 
to preserve the environmental conditions of a watershed for achieving sustainable water sources.

\section{2) The Combination of Population Growth Control and Land Use Plan}

The rate of land use in dynamics modelling might be interfered since in the reality, the land use change is primarily performed by human factors instead of natural ones. Therefore, the expected rate of land use change can be strived in order to attain sustainable water availability. Based on Law No. 41/1999 on Forestry and Law No. 26/2007 on Spatial Planning, the protected area is at least $30 \%$ of the total watershed area. In accordance with the laws, with a total area of 19,814.72 ha, Aek Silang sub-watershed should have 5,944.42 ha of forest cover area. Total forest cover and HTI is 2,781,170 ha, which makes the total protected area should be at least 8,725.49 ha. The changes of other types of land use were determined with the same assumption as mentioned above. It was confirmed by Kotir, et al. (2016), who suggested the alternative policy scenarios (ie., Law No. 41/1999 on Forestry and Law No. 26/2007) for sustainable water resource management and land use management.

The results of dynamics modelling to predict the water availability by examining the combination of population growth rate by $1.4 \%$ and land use simultaneously yielded the water surplus of $71,654,239 \mathrm{~m}^{3}$ in 2010 . The simulation of dynamics modelling by decreasing the population growth rate by $1.4 \%$ and land use, simultaneously, resulted a surplus of potential water sources amounted to $202,136 \mathrm{~m}^{3}$ in compared with the result of mainly reducing the population growth, which was $71,452,103$ $\mathrm{m}^{3}$.

\section{Conclusion}

Condition of environment which results the sustainable water resources utilization is when the area of forest cover is 8,607.58 ha, the area of agriculture (cultivation) is $10,054.86$ ha, the area of shrubs/open land is 0 ha, settlement area $98.93 \mathrm{ha}$, the area of ricefield is 1,053.35 ha, and total population is $2,408,995$ persons.

The change of land use affected to water resource availability which can be used because related to evapotranspiration and the ability of plant in holding water inside the soil. The water availability used was affected by people growth rate, so the control of people growth rate is required to maintain water availability. The management of land use and people growth in the same time is an effective way to prevent water availability.

This study presents feasibility of system dynamics simulation as an assessment tool to support the decision for maintaining water availability. It presents the ability of system dynamics to support the decision by generating future water availability data with different scenarios.

\section{References}

Asdak, C., 2010. Hidrologi dan Pengelolaan DAS, Gadjah Mada University Press, Yogyakarta.

Asner, G.P., Loarie, S.R., Heyder, U., 2010, Combined Effects of Climate and Land-use Change on the Future of Humid Tropical Forests, Conservation Letters, 3: 395-403.

Chung, G., Joong, H.K., Kim, T.W., 2008, System Dinamics Modelling Approach to Water Supply System, KSCE Journal of Civil Engineering, Vol. 12, No. 4: 275-280.

Hartono, Meteray, T.B.S., Farda, N.M., Kamal, M., 2006, Kajian Ekosistem Air Permukaan Rawa Biru - Torasi Merauke Papua Menggunakan Citra Penginderaan Jauh dan SIG, Forum Geografi, Vol. 20 (1) : 1 - 12

Hartrisari, 2007, Sistem Dinamik: Konsep Sistem dan Pemodelan untuk Industri dan Lingkungan, Seameo Biotrop Institut Pertanian Bogor, Bogor.

Hirijanto, Subandiyah A., Edi H.D.P., Ibnu H.P.J., 2013, Metode Global Plantasion Sistem untuk Antisipasi Dampak Perubahan Iklim (Kajian Daerah Irigasi Molek Kabupaten Malang), Konferensi Nasional Teknik Sipil 7 (KoNTekS 7) Universitas Sebelas Maret (UNS), Surakarta.

Igbawua, T., Zhang, J., Chang, Q., Yao, F., 2016, Vegetation Dynamics in Relation with Climate Over Nigeria from 1982 to 2011, Environment Earth Science, 75: 518. 
Indarto, 2010, Hidrologi Dasar Teori dan Contoh Aplikasi Model Hidrologi, PT.Bumi Aksara, Jakarta.

Indra, T.L., 2013, Dampak Penggunaan Lahan Terhadap Tingkat Kekritisan Air Sub DAS Citarum Hulu, Majalah Geografi Indonesia, Vo. 27 No.1: 26-37.

Jiang, Q., Wang, Z., and Fu, Q., 2012, Dynamic Simulation of Water Resources Sustainable Utilization of Kiamusze Based on System Dynamics, Computer and Computing Technologies in Agriculture, VI : 367 - 375.

Kotir, J.H., Smith, C., Brown, G., Marshall, N., Johnstone, R., 2016, A system dynamics simulation model for sustainable water resources management and agricultural development in the Volta River Basin, Ghana, Science of the Total Environment, Vol. 573 : $444-457$.

Liu, Y., 2005, Land Use/Cover Changes, the Environment and Water sources in Northeast China, Environmental Management Vol. 36 No.5: 691-701.

Liu, Y., Yaning, C., 2006, Impact of Population Growth and Land-use Change on Water sources and Ecosystems of the Arid Tarim River Basin in Western China, International Journal of Sustainable Development and World Ecology Vol. 13: 295-305.

Mirchi, A., Madani, K., Watkins, D.Jr., Ahmad, S, 2012, Synthesis of System Dynamics Tools for Holistic Conceptualization of Water Resources Problema, Water Resour Manage, Vol. 26 : $2421-2442$.

Muta'ali, L., 2011. Environmental Carrying Capacity Based on Spatial Planning, Indonesian Journal of Geography, Vo. 43 (2): 142-155.

Narulita, I, 2007, Distribusi Spasial dan Temporal Curah Hujan Rata-rata Tahunan Tipe Orografik untuk Menduga Angka Koefisien Aliran di Cekungan Bandung, dalam Sumber Daya Air dan Lingkungan Potensi, Degradasi dan Masa Depan, Diedit oleh Delinom, R.M., Dyah M, Jakarta: LIPI Press, p. 197.

Purnama, S., 2008, The Potential of Rainfall and Its Impact to Groundwater Storage in Java Island, Indonesia Journal of Geography Vol. 40 No. 2: 153-166.

Purnama, S., Kurniawan, A., Sudaryanto, 2006, Model Konservasi Air Tanah di Dataran Pantai Kota Semarang, Forum Geografi, Vol. 20 (2) : 160 - 174.

Purnomo, H., 2012, Pemodelan dan Simulasi untuk Pengelolaan Adaptif Sumber Daya Alam dan Lingkungan, IPB Press, Bogor.

Rachmat, A., 2007, Dampak Perubahan Tata Guna Lahan Terhadap Ketersediaan Air Tanah di DAS Citanduy Berdasarkan Koefisien Infiltrasi, dalam Sumber Daya Air dan Lingkungan Potensi, Degradasi dan Masa Depan, Diedit oleh Delinom, R.M., Dyah M, Jakarta: LIPI Press, p. 21.

Sitompul, R.F., 2009, Merancang Model Pengembangan Masyarakat Pedesaan dengan Pendekatan System Dinamics, Penerbit LIPI, Jakarta.

Somantri, A.S., and Machfud, 2006, Analisis Sistem Dinamika untuk Kebijakan Penyediaan Ubi Kayu : (Studi Kasus di Kabupaten Bogor), Buletin Teknologi Pascapanen Pertanian, Vol. 2: 36-48.

Soedarjanto, S., Sartohadi, J., Hadi, M.P., Danoedoro, P., 2011. The Role of Vegetation Cover and Catchment Characteristics on Baseflow in Bali Island, Indonesia Journal of Geography, 43 (2): $97-110$.

Takeda, K., 1993, Hidrologi untuk Pengairan, PT. Pradnya Paramita, Jakarta.

Wiyono, S., 2012, Penggunaan Sistem Dinamik Dalam Manajemen Transportasi untuk Mengatasi Kemacetan di Daerah Perkotaan, Jurnal Transpotasi, Vol. 12, No. 1: 1-10.

Xi Xi and Poh, K.L., 2013, Using system dynamics for sustainable water resources management in Singapore, Procedia Computer Science, Vol. 16 : 157 - 166 
Yulianto, K., 2007, Menciptakan Generasi yang Arif Lingkungan: Sebuah Sumbangan Pemikiran Melalui Model Pendidikan Lingkungan Hidup, Jurnal Universitas Paramadina, Vol. 05 No. 1: 15-23.

Zeppel, M.J.B., Wilks, J.V., Lewis, J.D., 2014, Impacts of Extreme Precipitation and Seasonal Change In Precipitation on Plants, Biogeosiciences, Vol.11: 3083-3093.

6. Appendix

Appendix 1. The Availability of Potential Utilized Water Sources.

\begin{tabular}{|c|c|c|c|c|}
\hline Year & $\begin{array}{c}\text { Potential Water } \\
\qquad\left(\mathbf{m}^{3}\right)\end{array}$ & $\begin{array}{l}\text { Potential Utilized } \\
\text { Water }\left(\mathrm{m}^{3}\right)\end{array}$ & $\begin{array}{l}\text { Evapo- } \\
\text { transpiration }\left(\mathrm{m}^{3}\right)\end{array}$ & $\begin{array}{l}\text { Soil Moisture Vol- } \\
\text { ume }\left(\mathrm{m}^{3}\right)\end{array}$ \\
\hline 2011 & 458.134 .160 & 298.858 .733 & 146.731 .718 & 12.538 .755 \\
\hline 2012 & 458.050 .938 & 297.139.470 & 148.367.759 & 12.538 .755 \\
\hline 2013 & 457.967 .716 & 295.420.207 & 150.003 .800 & 12.538 .755 \\
\hline 2014 & 457.884 .494 & 293.700 .944 & 151.639 .841 & 12.538 .755 \\
\hline 2015 & 457.801 .272 & 291.981.681 & 153.275.882 & 12.538 .755 \\
\hline 2016 & 457.718 .051 & 290.262 .418 & 154.911.924 & 12.538 .755 \\
\hline 2017 & 457.634 .829 & 288.590 .387 & 156.500 .734 & 12.538 .755 \\
\hline 2018 & 457.551 .607 & 288.587.405 & 156.420 .493 & 12.538 .755 \\
\hline 2019 & 457.468 .385 & 288.584 .424 & 156.340 .252 & 12.538 .755 \\
\hline 2020 & 457.385 .163 & 288.581 .443 & 156.260 .012 & 12.538 .755 \\
\hline 2089 & 451.642 .857 & 288.375 .739 & 150.723 .410 & 12.538 .755 \\
\hline 2090 & 451.559 .636 & 288.372.758 & 150.643 .169 & 12.538 .755 \\
\hline 2091 & 451.476 .414 & 288.369.777 & 150.482 .688 & 12.538 .755 \\
\hline 2092 & 451.393 .192 & 288.366.796 & 150.402 .447 & 12.538 .755 \\
\hline 2093 & 451.309 .970 & 288.363.814 & 150.402 .447 & 12.538 .755 \\
\hline 2094 & 451.226 .748 & 288.360 .833 & 150.322 .206 & 12.538 .755 \\
\hline 2095 & 451.143 .526 & 288.357.852 & 150.241 .966 & 12.538 .755 \\
\hline 2096 & 451.060 .305 & 288.354 .871 & 150.161 .725 & 12.538 .755 \\
\hline 2097 & 450.977 .083 & 288.351 .890 & 150.081.485 & 12.538 .755 \\
\hline 2098 & 450.893 .861 & 288.348 .908 & 150.001 .244 & 12.538 .755 \\
\hline 2099 & 450.810 .639 & 288.345 .927 & 149.921 .003 & 12.538 .755 \\
\hline 2100 & 450.727 .417 & 288.342 .946 & 149.840 .763 & 12.538 .755 \\
\hline
\end{tabular}

Source: Data analysis, 2016.

Appendix 2. The water demand of each sector in $2011-2100$

\begin{tabular}{cccccc}
\hline Year & $\begin{array}{c}\text { Total Population } \\
\text { (person) }\end{array}$ & $\begin{array}{c}\text { Domestic } \\
\left(\mathbf{m}^{3}\right)\end{array}$ & Paddy Field $\left(\mathbf{m}^{3}\right)$ & $\begin{array}{c}\text { MHP Plant } \\
\left(\mathbf{m}^{3}\right)\end{array}$ & $\begin{array}{c}\text { Total water } \\
\text { demand }\left(\mathbf{m}^{3}\right)\end{array}$ \\
\hline 2011 & 13,924 & 406,581 & $10,921,133$ & $204,984,000$ & $216,311,714$ \\
2012 & 14,875 & 434,350 & $10,921,133$ & $204,984,000$ & $216,339,483$ \\
2013 & 15,891 & 464,016 & $10,921,133$ & $204,984,000$ & $216,369,149$ \\
2014 & 16,976 & 495,709 & $10,921,133$ & $204,984,000$ & $216,400,842$ \\
2015 & 18,136 & 529,566 & $10,921,133$ & $204,984,000$ & $216,434,698$ \\
2016 & 19,374 & 565,735 & $10,921,133$ & $204,984,000$ & $216,470,868$ \\
2017 & 20,698 & 604,374 & $10,921,133$ & $204,984,000$ & $216,509,507$ \\
2018 & 22,111 & 645,653 & $10,921,133$ & $204,984,000$ & $216,550,786$ \\
2019 & 23,622 & 689,751 & $10,921,133$ & $204,984,000$ & $216,594,884$ \\
\hline
\end{tabular}




\begin{tabular}{cccccc}
\hline Year & $\begin{array}{c}\text { Total Population } \\
\text { (person) }\end{array}$ & $\begin{array}{c}\text { Domestic } \\
\left(\mathbf{m}^{3}\right)\end{array}$ & Paddy Field $\left(\mathbf{m}^{3}\right)$ & $\begin{array}{c}\text { MHP Plant } \\
\left(\mathbf{m}^{3}\right)\end{array}$ & $\begin{array}{c}\text { Total water } \\
\text { demand }\left(\mathbf{m}^{3}\right)\end{array}$ \\
\hline 2020 & 25,235 & 736,861 & $10,921,133$ & $204,984,000$ & $216,641,994$ \\
2089 & $2,408,995$ & $70,342,642$ & $10,921,133$ & $204,984,000$ & $286,247,775$ \\
2090 & $2,573,529$ & $75,147,045$ & $10,921,133$ & $204,984,000$ & $291,052,178$ \\
2091 & $2,749,301$ & $80,279,588$ & $10,921,133$ & $204,984,000$ & $296,184,721$ \\
2092 & $2.937,078$ & $85,762,684$ & $10,921,133$ & $204,984,000$ & $301,667,817$ \\
2093 & $3,137,681$ & $91,620,275$ & $10,921,133$ & $204,984,000$ & $307,525,408$ \\
2094 & $3,351,984$ & $97,877,940$ & $10,921,133$ & $204,984,000$ & $313,783,073$ \\
2095 & $3,580,925$ & $104,563,004$ & $10,921,133$ & $204,984,000$ & $320,468,137$ \\
2096 & $3,825,502$ & $111,704,657$ & $10,921,133$ & $204,984,000$ & $327,609,790$ \\
2097 & $4,086,784$ & $119,334,085$ & $10,921,133$ & $204,984,000$ & $335,239,218$ \\
2098 & $4,365,911$ & $127,484,603$ & $10,921,133$ & $204,984,000$ & $343,389,736$ \\
2099 & $4,664,103$ & $136,191,801$ & $10,921,133$ & $204,984,000$ & $352,096,934$ \\
2100 & $4,982,661$ & $145,493,701$ & $10,921,133$ & $204,984,000$ & $361,398,834$ \\
\hline
\end{tabular}

Source: Data analysis, 2016.

Appendix 3. Data of Water Demand in Dynamic Modelling.

\begin{tabular}{|c|c|c|c|}
\hline No. & Sector & Value & Source \\
\hline 1. & $\begin{array}{l}\text { Domestic needs } \\
\text { a. Total population in } 2011 \\
\text { b. Population growth rate } \\
\text { c. Population death rate } \\
\text { d. Water demand }\end{array}$ & $\begin{array}{r}13,924 \text { people } \\
7.23 \%(0.0723) \\
0.004 \\
80 \text { liter/individual/day }\end{array}$ & $\begin{array}{l}\text { Central Bureau of Statistic } \\
\text { Central Bureau of Statistic } \\
\text { Central Bureau of Statistic } \\
\text { Indonesia National Standard number : } \\
\text { 19-6728.1-2002 }\end{array}$ \\
\hline 2. & $\begin{array}{l}\text { Agriculture } \\
\text { a. Paddy field } \\
\text { b. Water demand } \\
\text { c. Crop intensity }\end{array}$ & $\begin{array}{r}1,053.35 \text { ha } \\
1 \text { liter/s / ha } \\
120 \text { days }\end{array}$ & $\begin{array}{l}\text { Interpretation Citra Landsat } \\
\text { Indonesia National Standard number : } \\
\text { 19-6728.1-2002 }\end{array}$ \\
\hline 3. & $\begin{array}{l}\text { Micro-Hydro Power Plant } \\
\text { a. Electric energy capacity } \\
\text { b. Water demand }\end{array}$ & $\begin{array}{c}750 \mathrm{kWh} \\
6.5 \mathrm{~m}^{3} / \mathrm{s}\end{array}$ & National Electricity Company \\
\hline
\end{tabular}




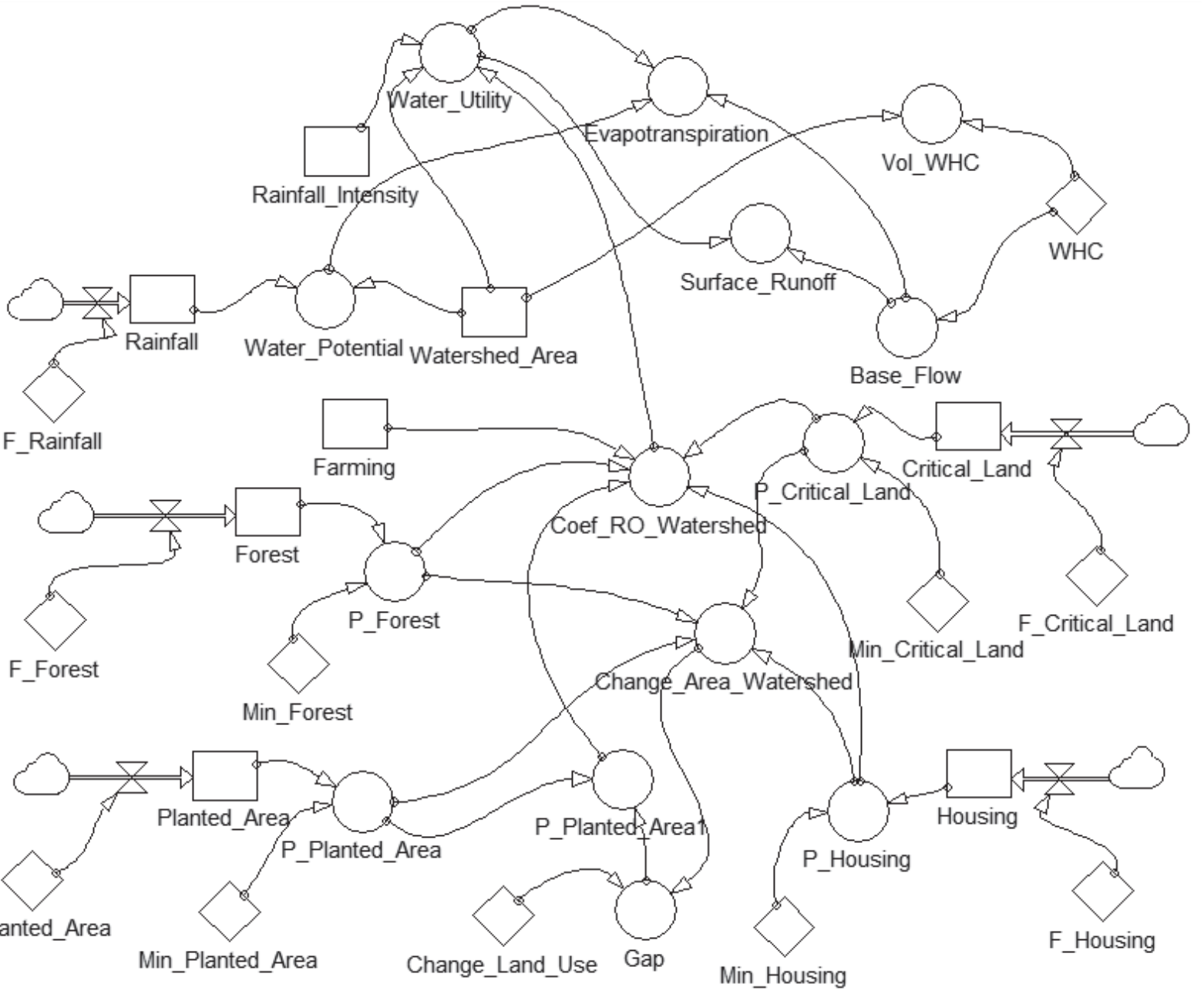

Appendix 4. Construction of Potential Utilized Water Resources in Dynamics Modelling

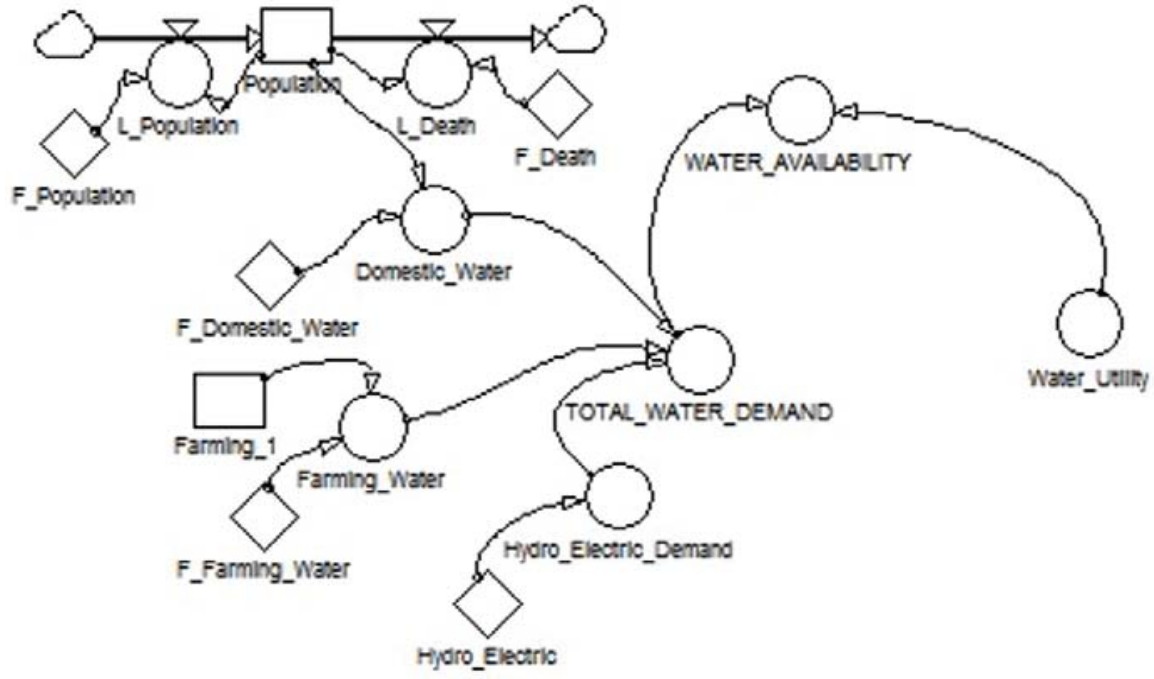

Appendix 5. Construction of Water Availability in Dynamics Modelling 